دراسات في آثار الوطن العربي 11

\title{
أسرار دور الضرب وصناعة النقود عند العرب
}

\section{أدـ ـ ناهض عبد الرزاق دفتر القيسين}

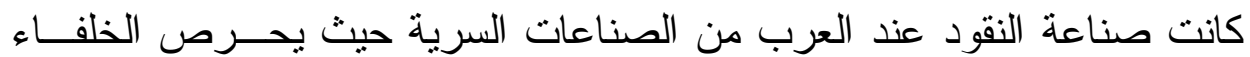

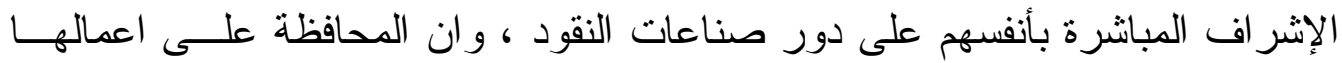

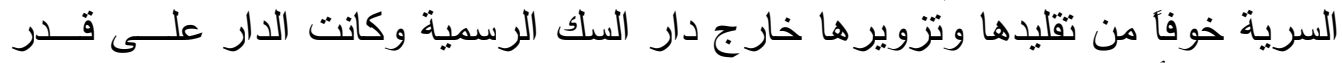

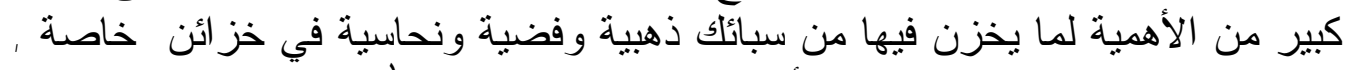

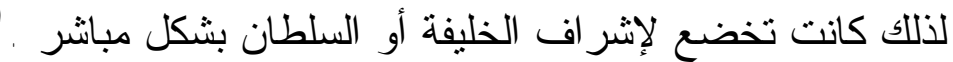

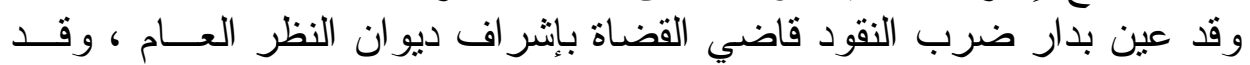

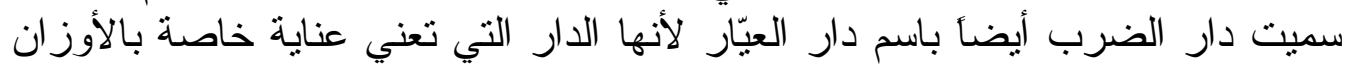

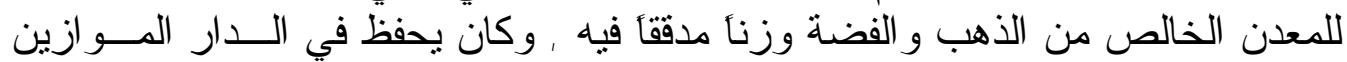

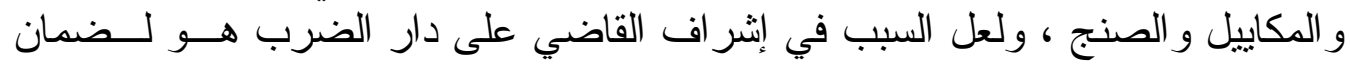

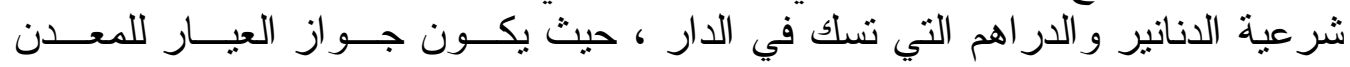

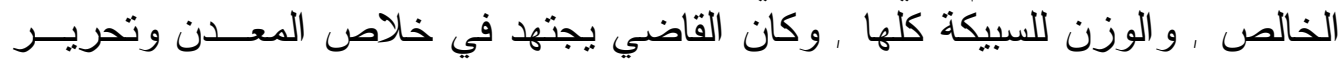

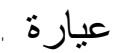
أما متولي دار الضرب فكانت له السلطة المباشرة على العمال في الدار , وومسن الإنس

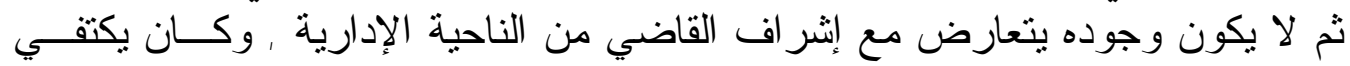

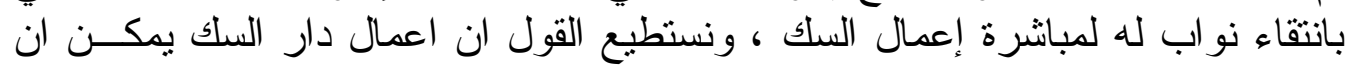

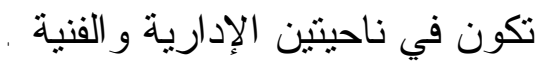

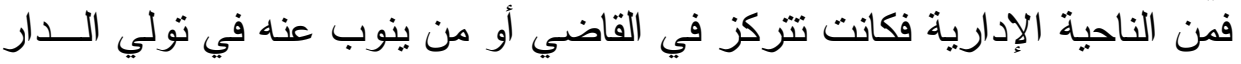
من المشرفين المبانشرين الإئمين.

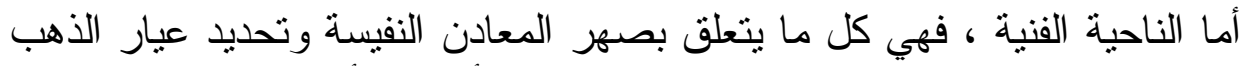

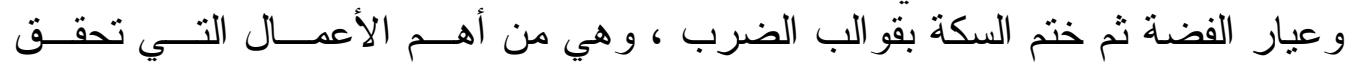

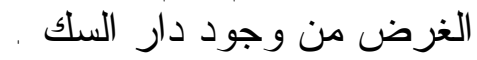
وكما ذكرنا بان الإثر اف المباشرة للخلفاء كان ذلك منذ تعريب المسكوكات فــي

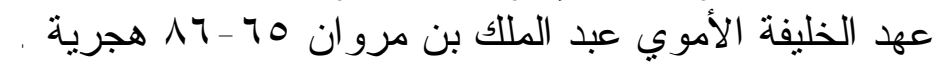

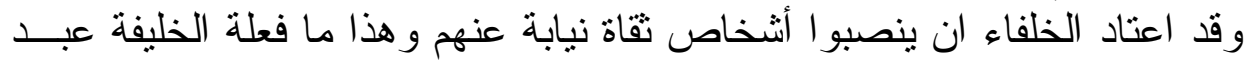

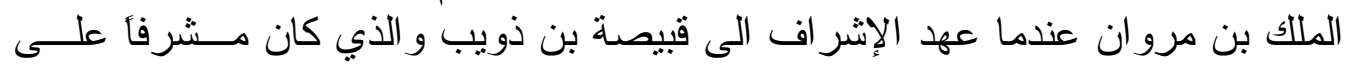

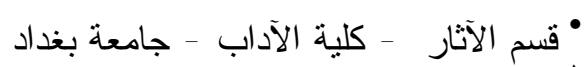

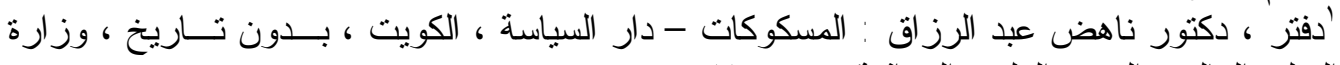

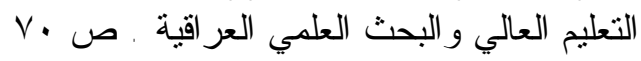




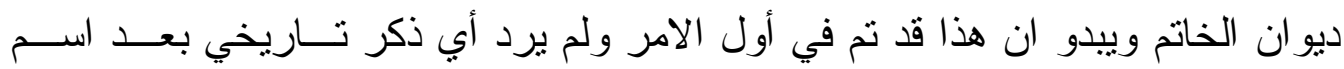

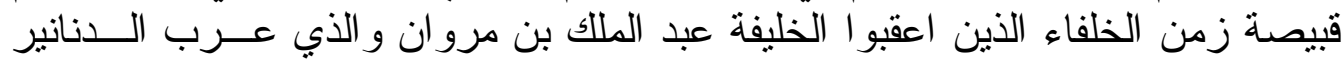

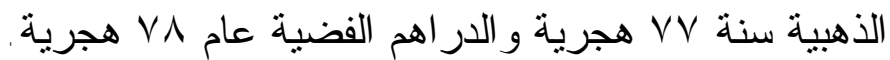

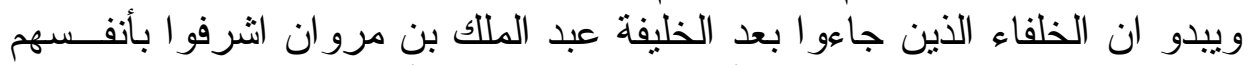

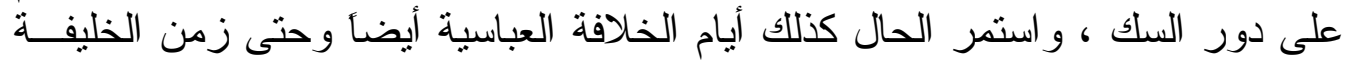

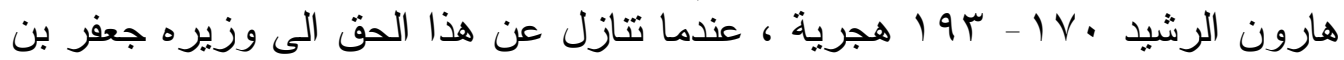

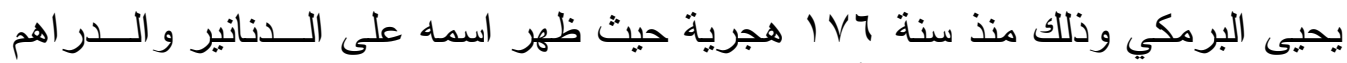

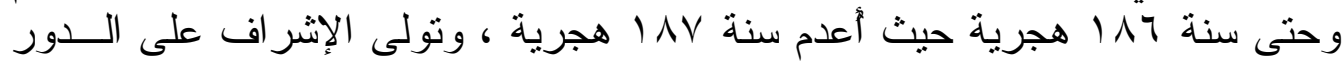

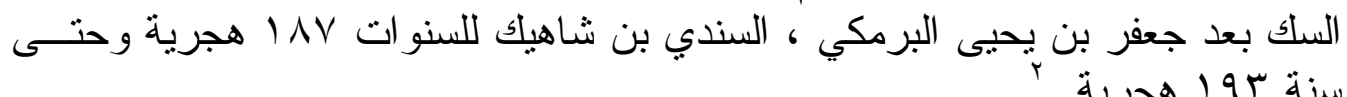
وفي عهد الخليفة محمد الأمين سو 19191 - 191 هجرية نصب العباس بن الفضل بن

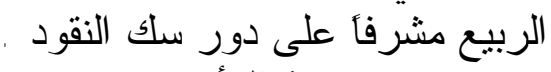

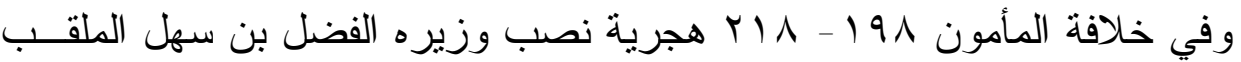

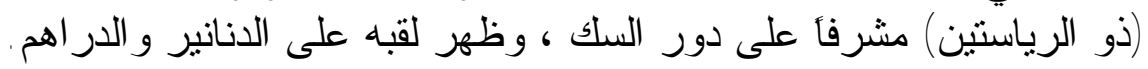

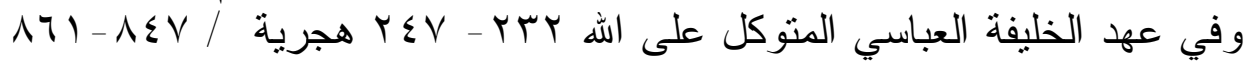

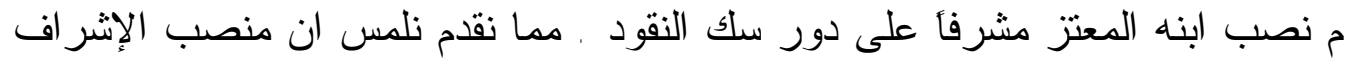

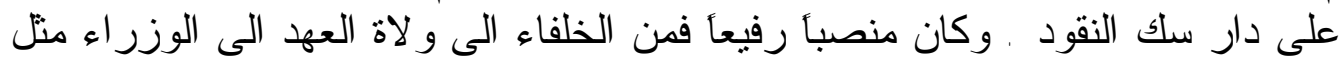

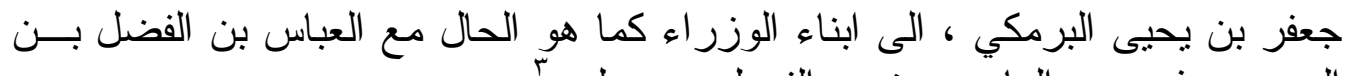

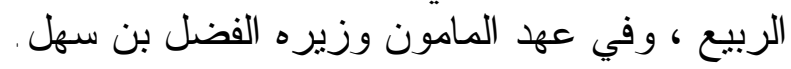

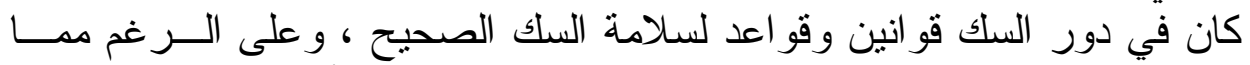

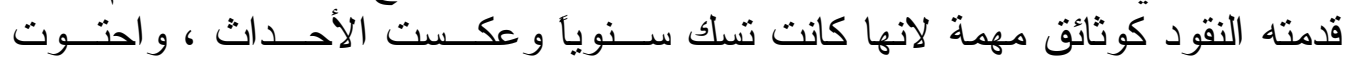

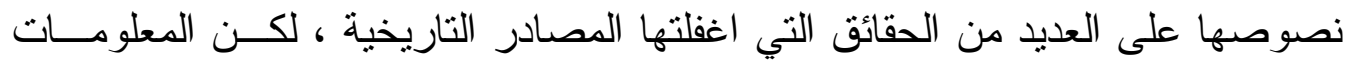

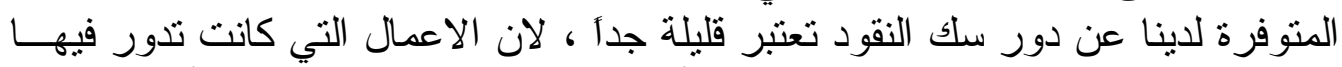

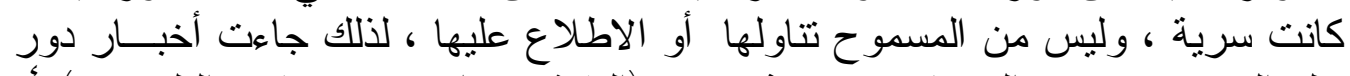

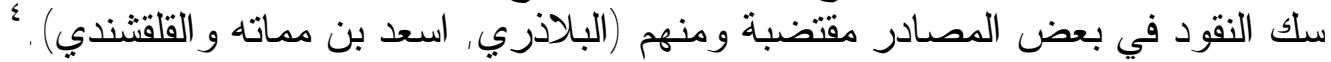

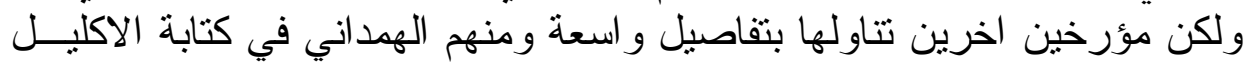

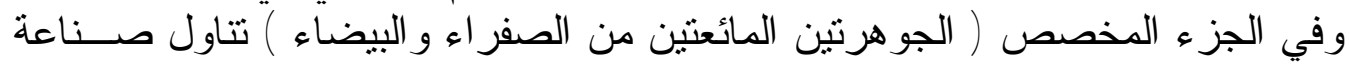

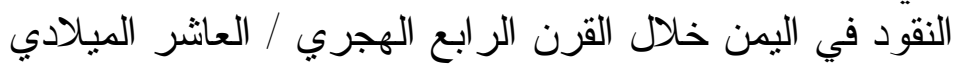

كوكتور خلف الطراونة ودكتور ناهض عبد الرزاق دفتز : المسكوكات وقر اءة التاريخ ، عمان

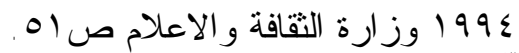

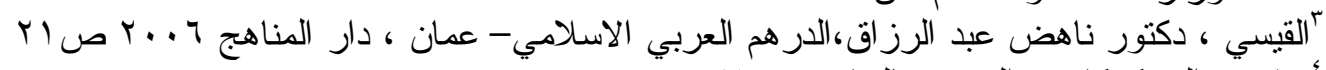

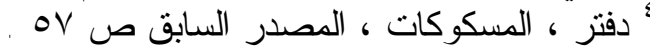




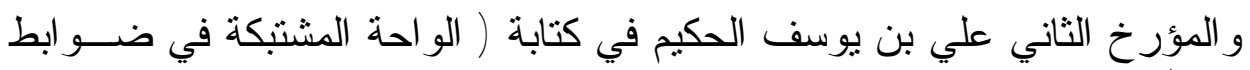

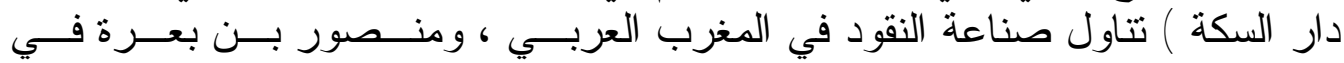

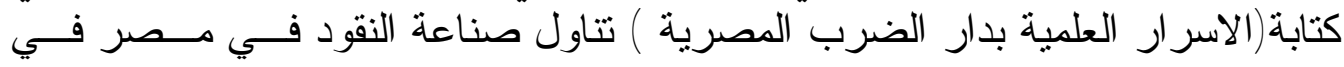

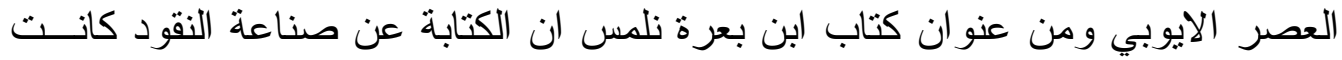

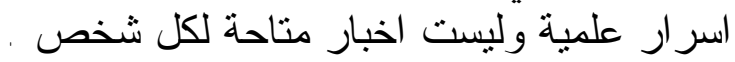

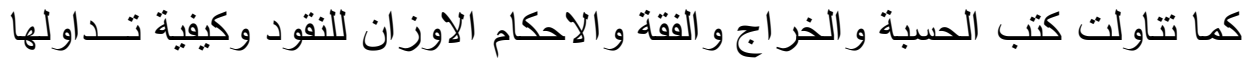

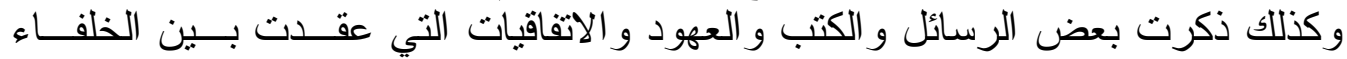

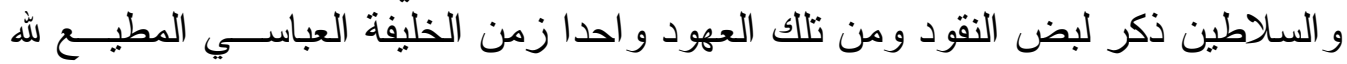

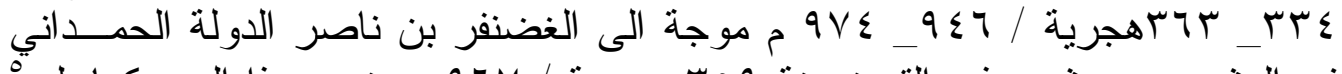

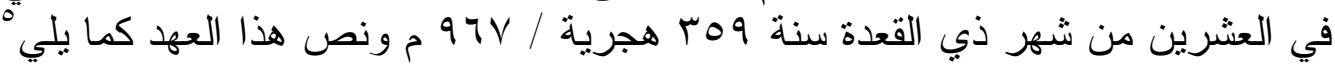

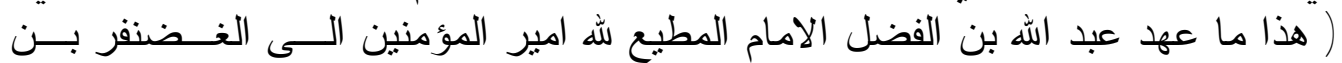

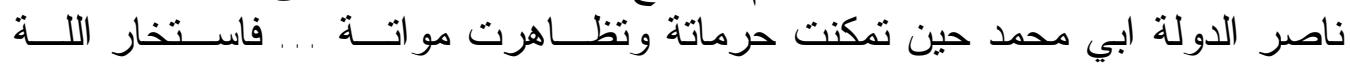

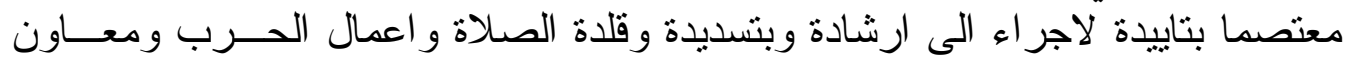

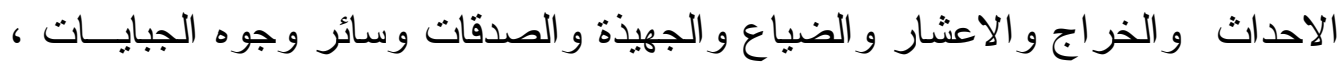

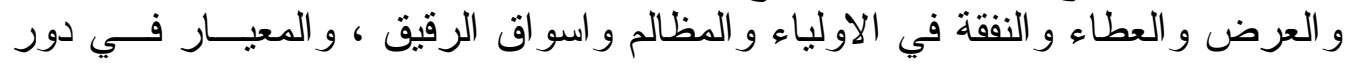

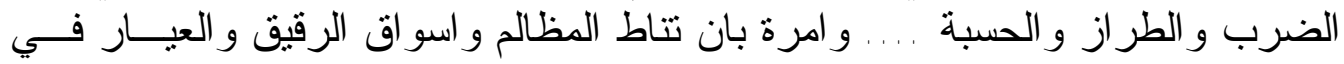

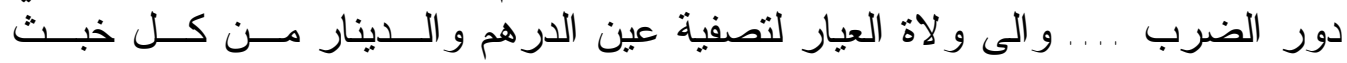

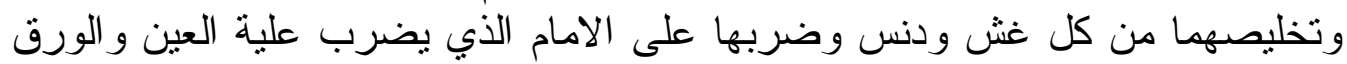

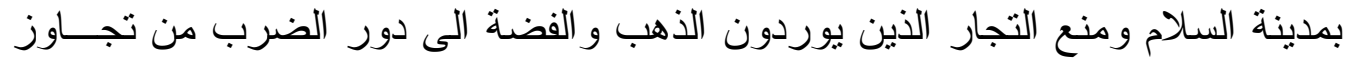

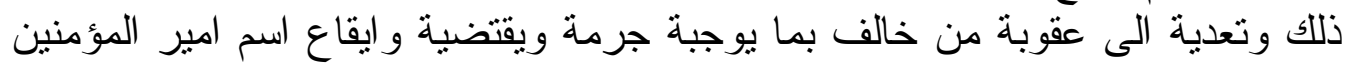

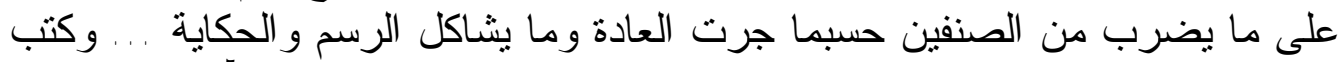

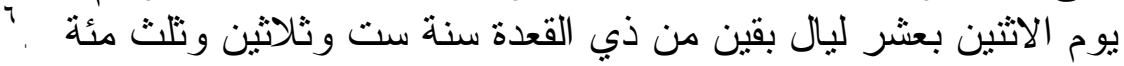

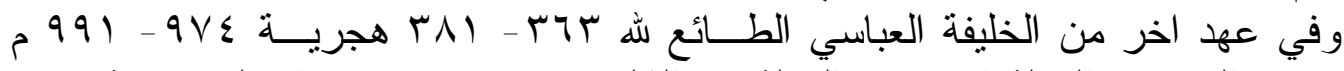

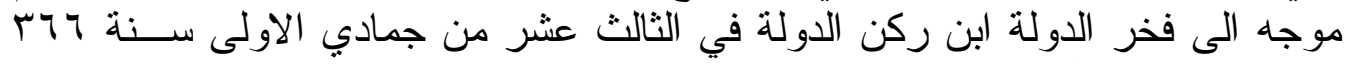

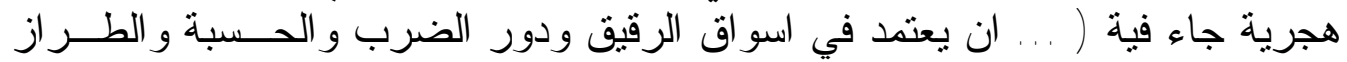

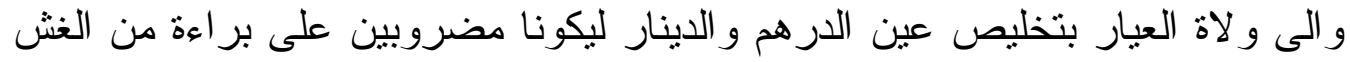

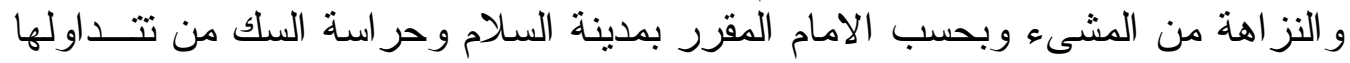

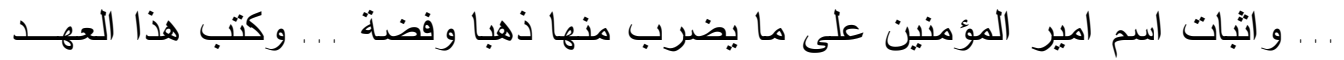

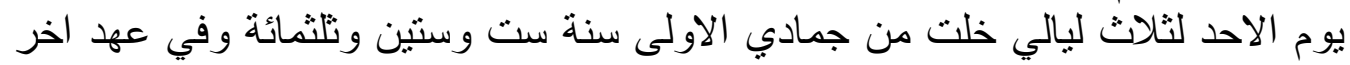

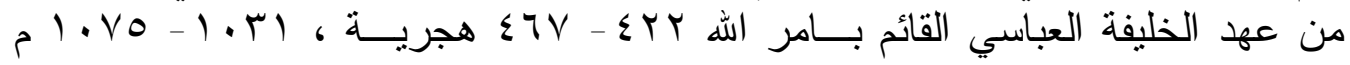

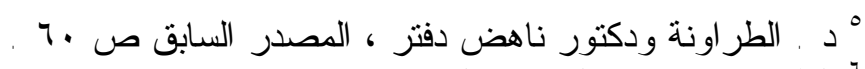

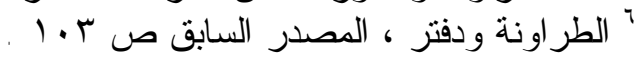




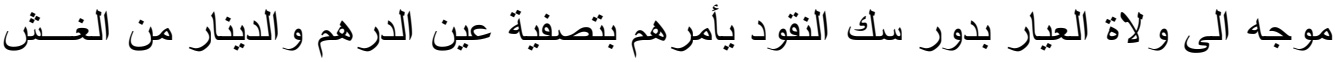

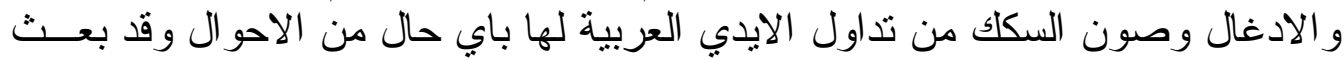

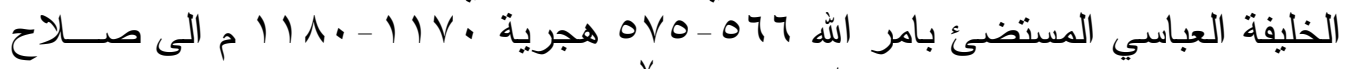

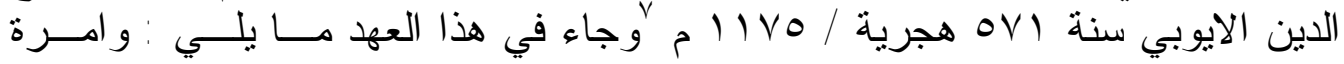

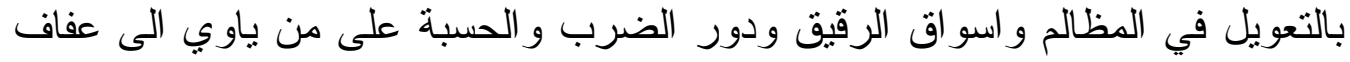

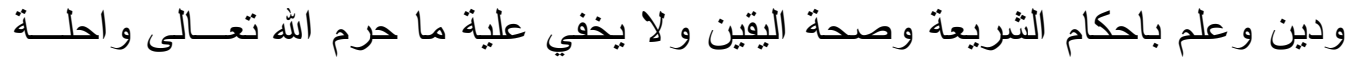

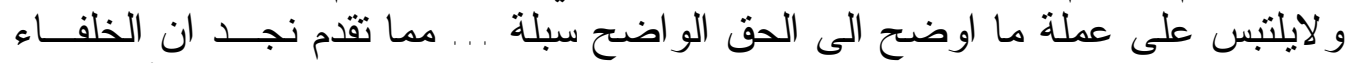

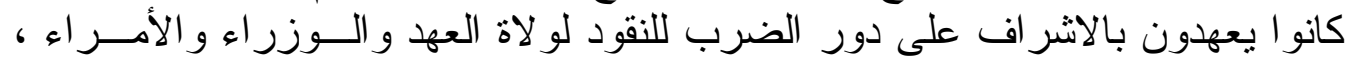

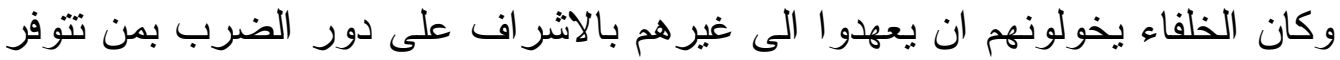

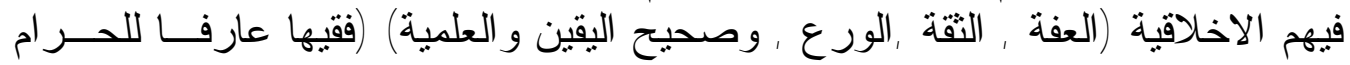

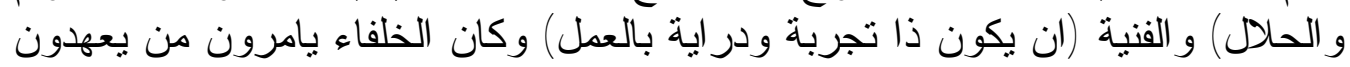

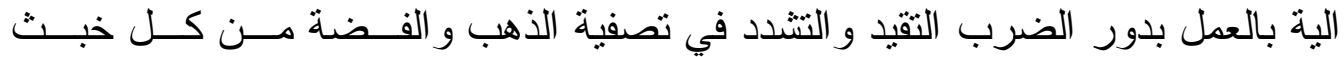

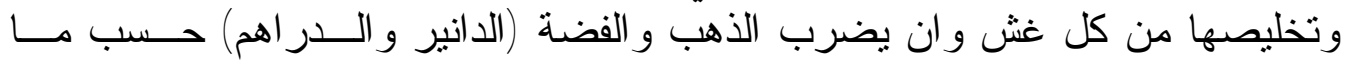

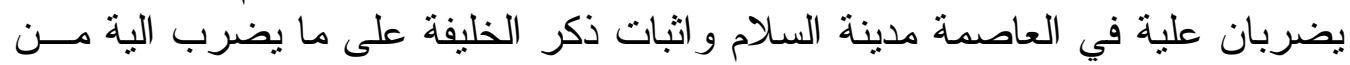

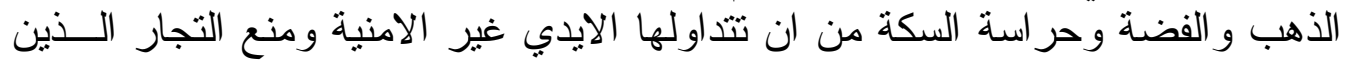

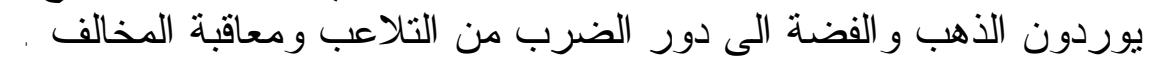

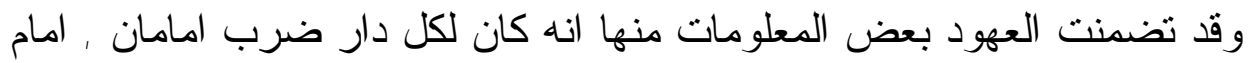

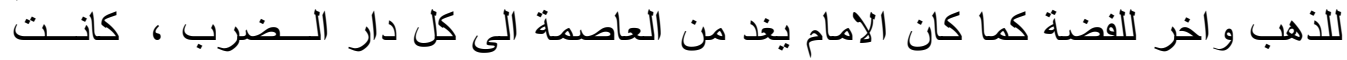

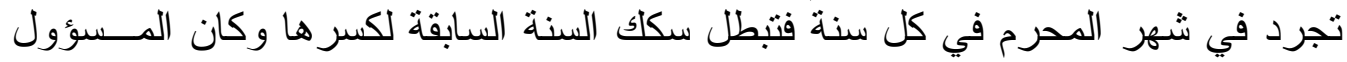

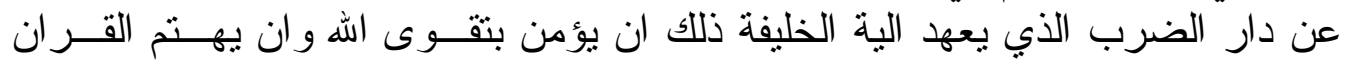

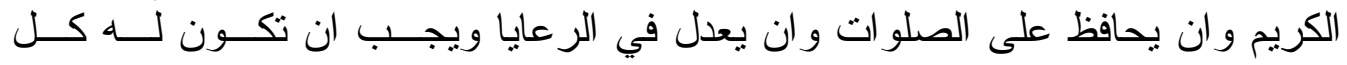

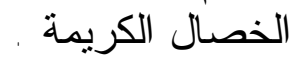

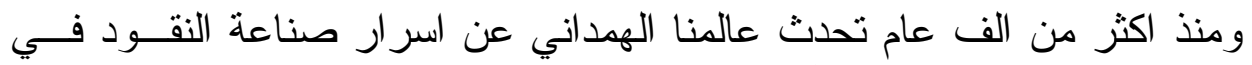

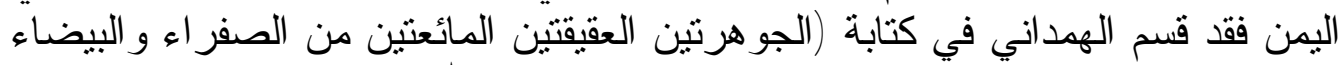

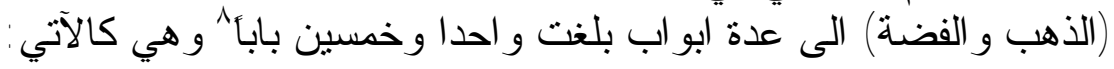

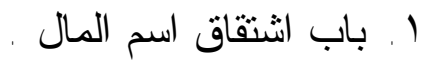

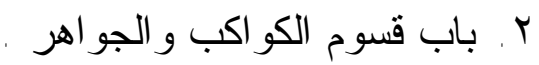

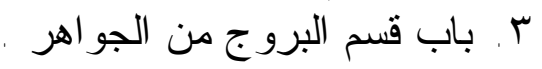

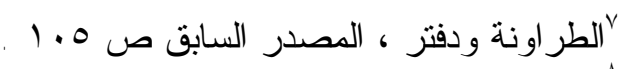

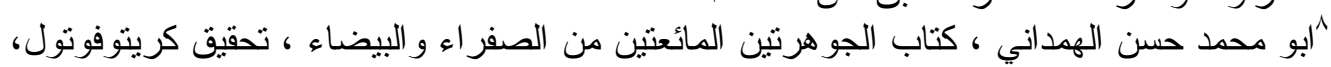

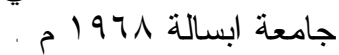
كتاب الاكليل الجزء الثاني ، حققه و علق عليه محمد بن علي الاكوع ، صنعاء 1977 م م. 
ع. . باب تكوّن الذهب و الفضة من معدنهما ونشأتهما بعد العدم .

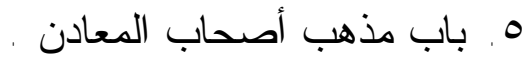

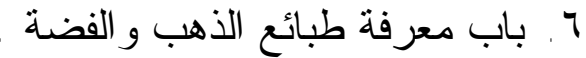

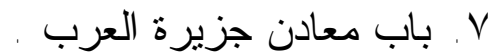

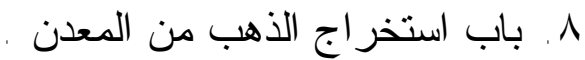

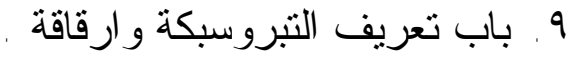

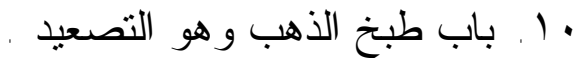

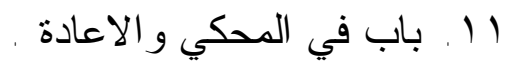

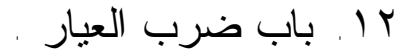

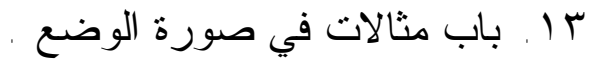

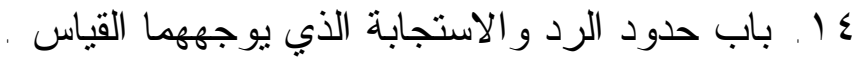

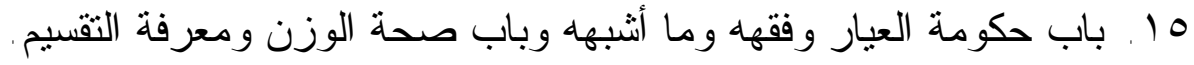

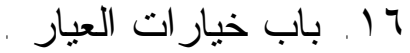

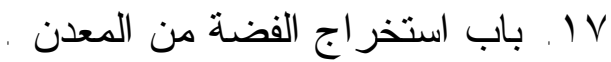

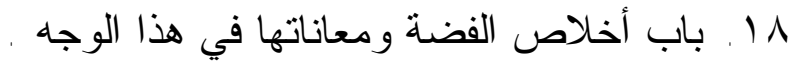

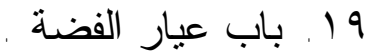

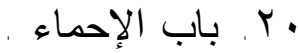

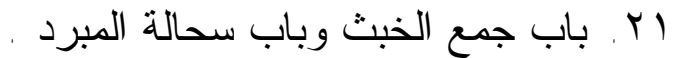

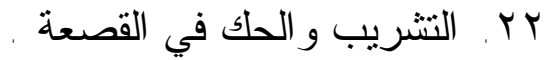

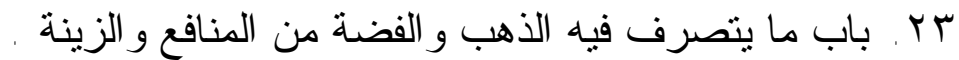

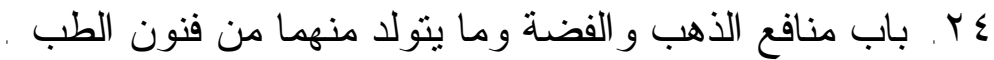

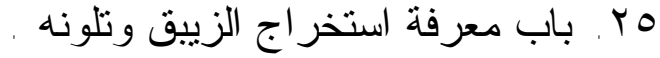

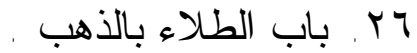
N rV

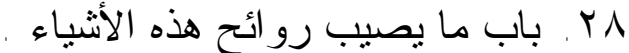

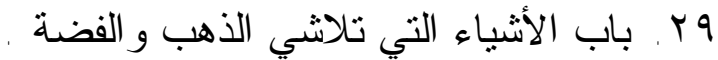

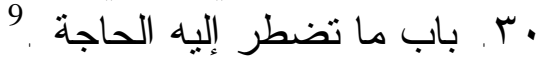

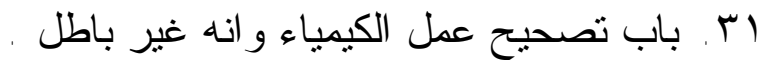

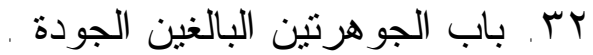
كتاب الاكليل المصدر السابق . 


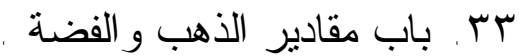
ع آ. باب الفرق ما بين ذهب المعدن وبين ذهب العيار ولما لا يعمل بهــذا المعــدن كل ما خلقة اله عز وجل عليه . هب. باب الفرق ما بين ذهب الصباغة وذهب الدينار ولما صار للحلية أردى.

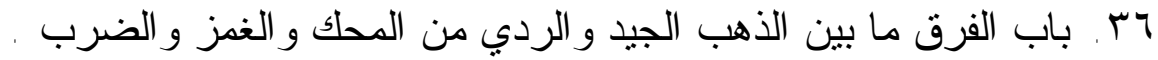
ي rV

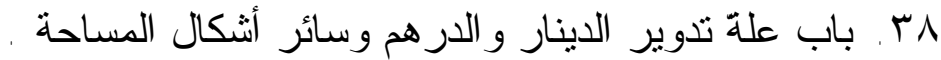

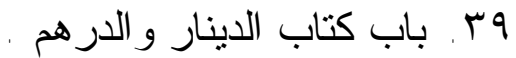

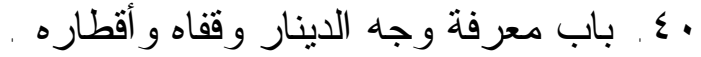

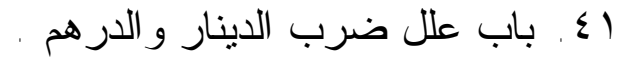
r r

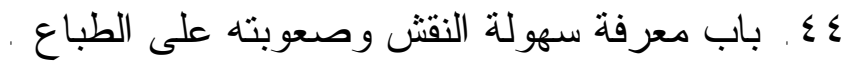

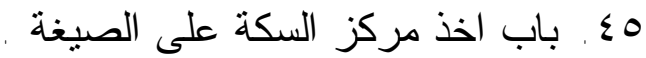

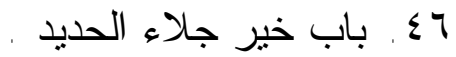

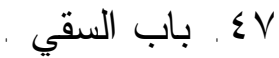

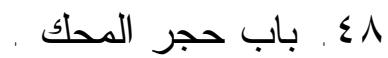

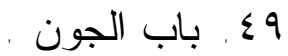

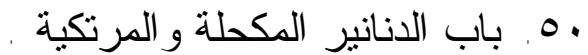

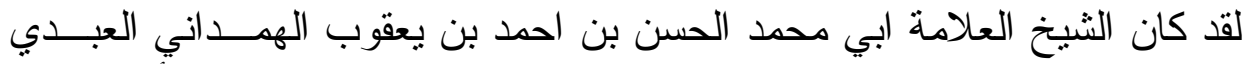

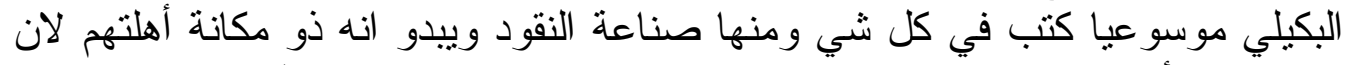

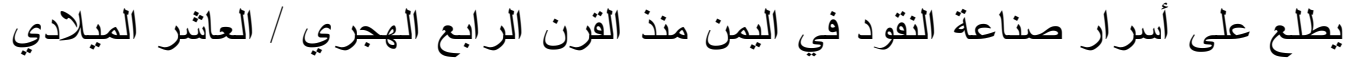

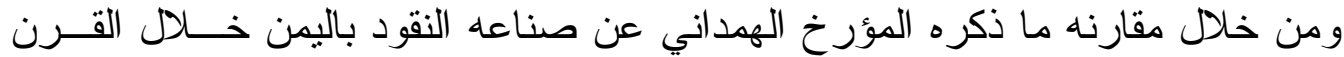

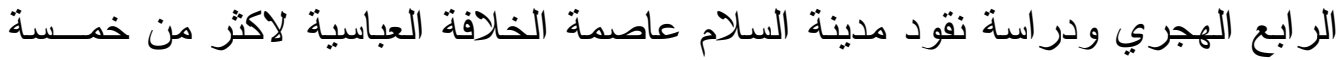

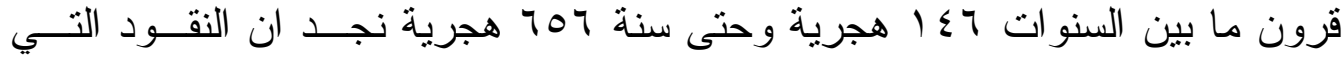

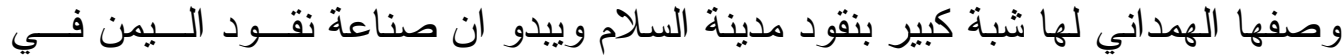

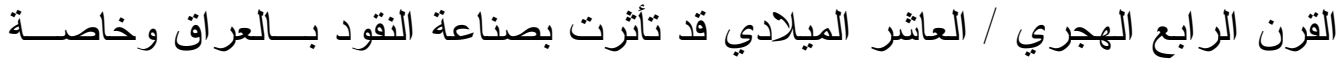

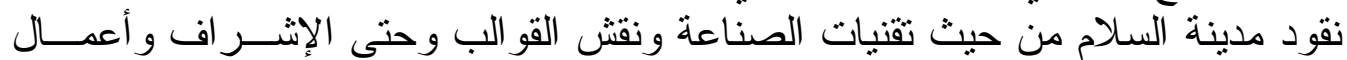

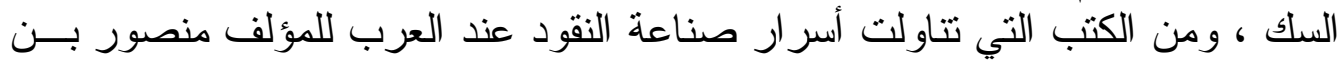

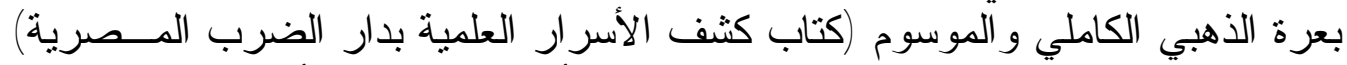

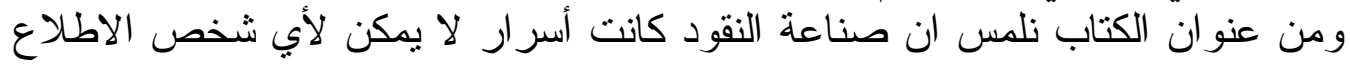




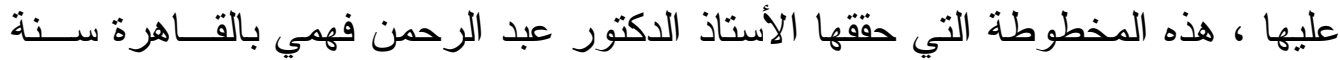

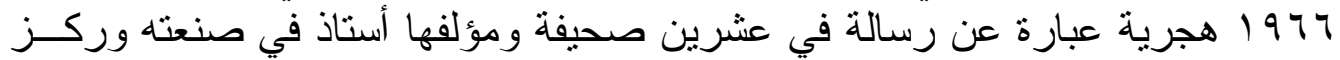

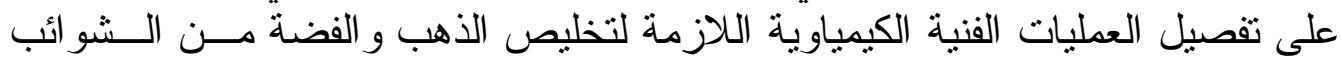

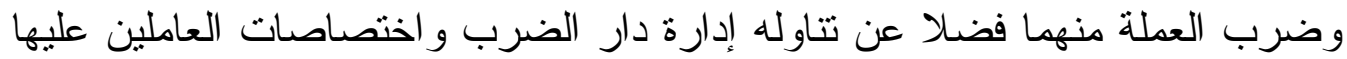

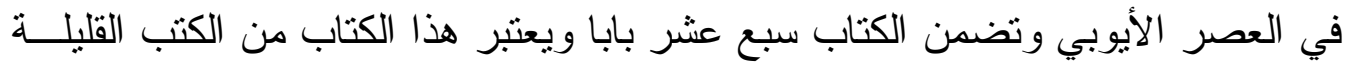

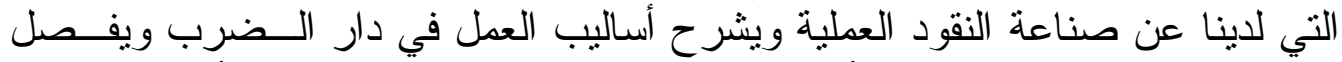

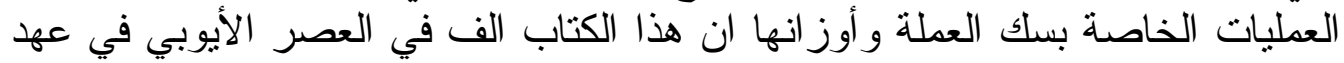

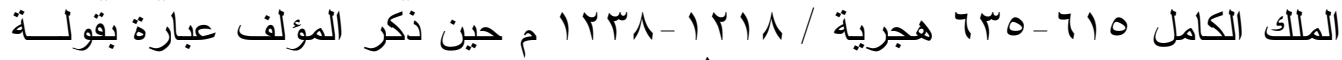

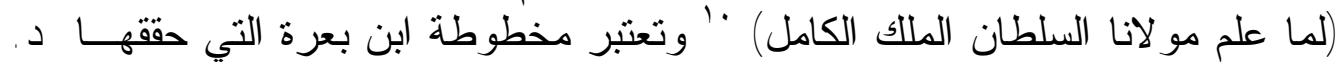

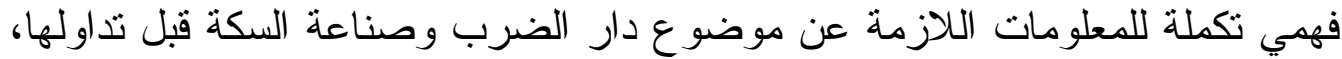

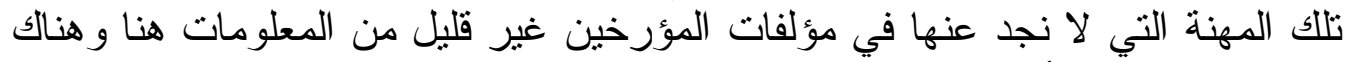

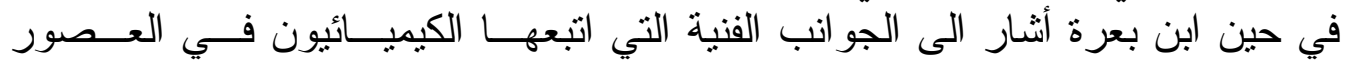

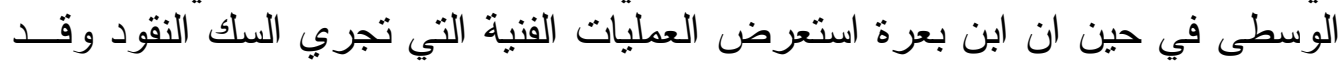

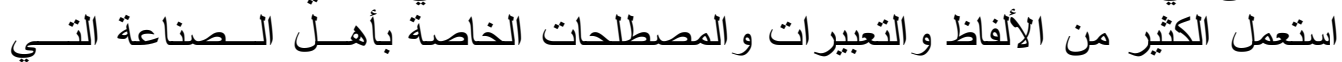

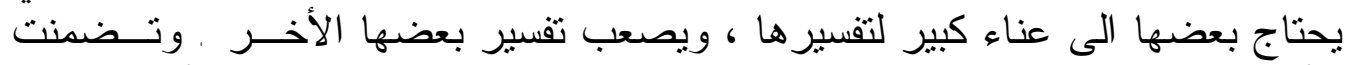

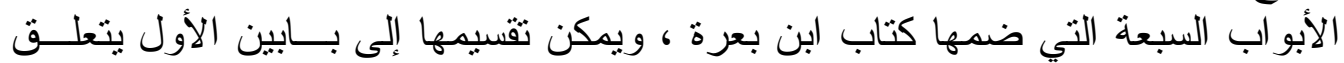

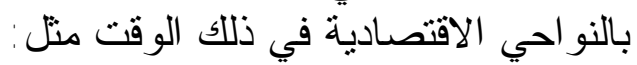

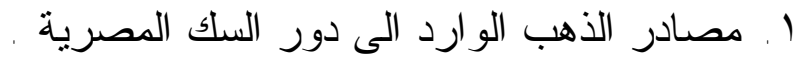

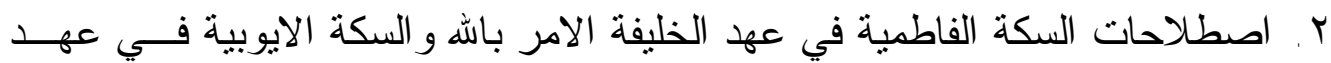
السلطان الكامل . التطان.

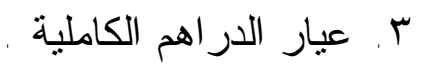

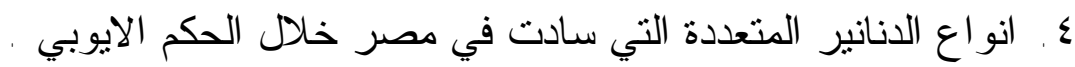

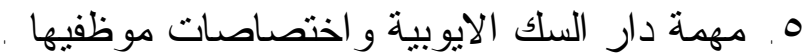

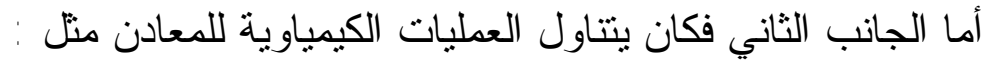

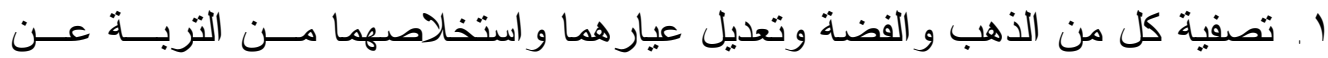

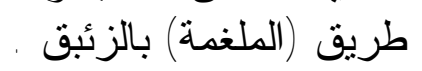

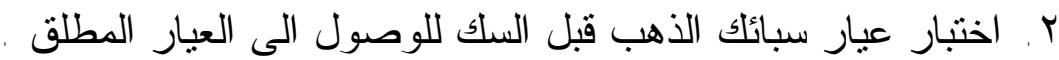

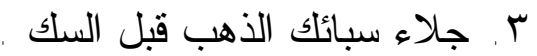

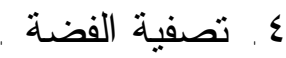

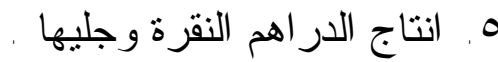

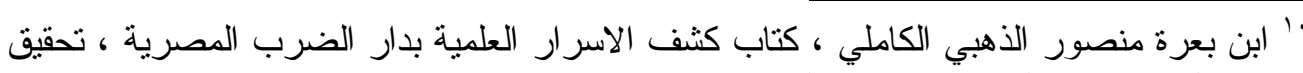

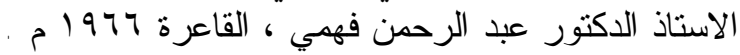




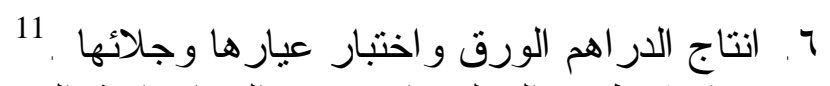

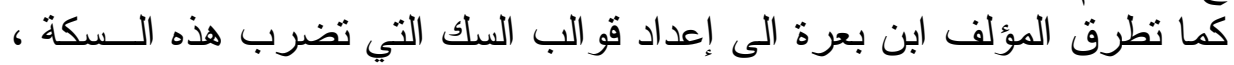

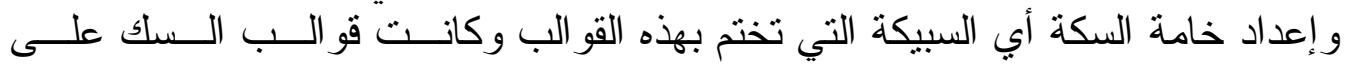

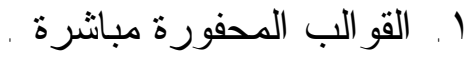

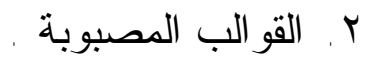

أما الخامات المعادن التي ذكر ها المؤلف و التي كانت ترد الى دار الضرب التهب هي :

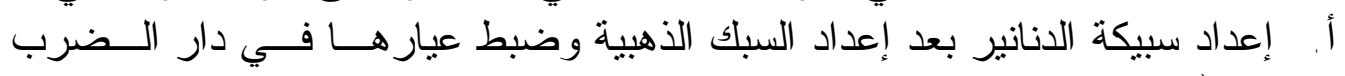

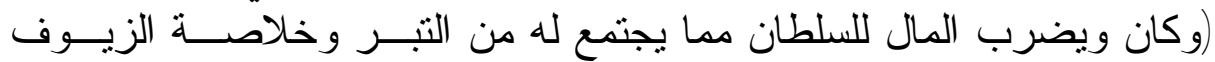

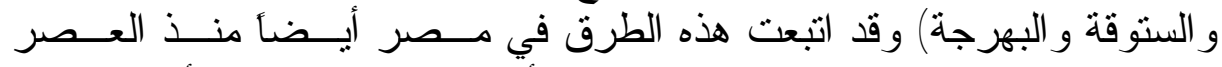

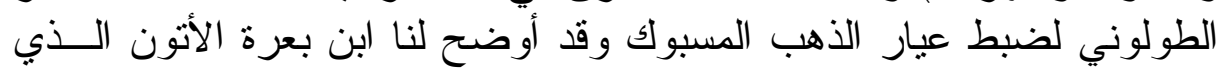

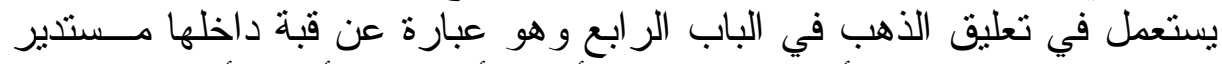

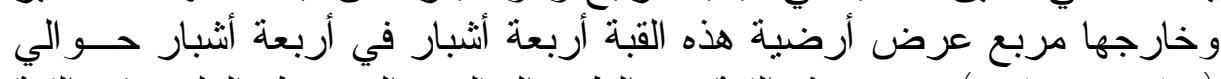

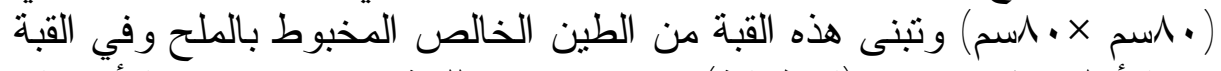

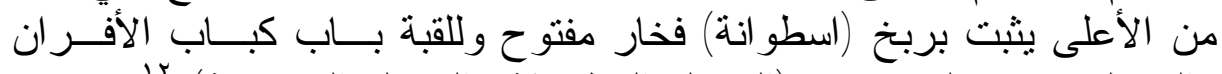

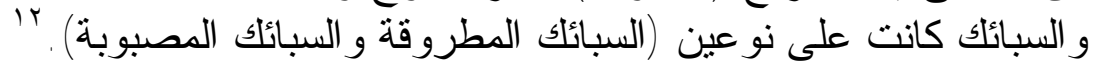

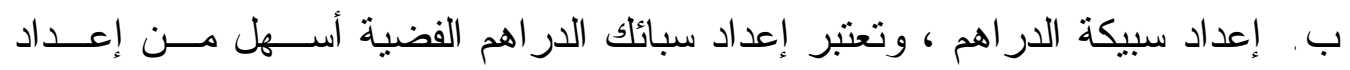

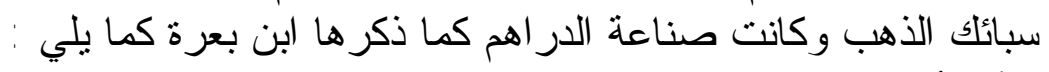

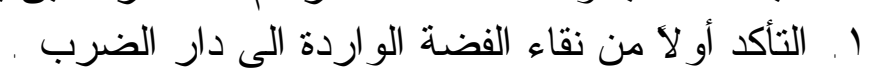

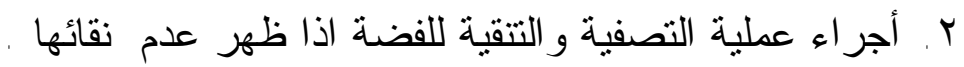

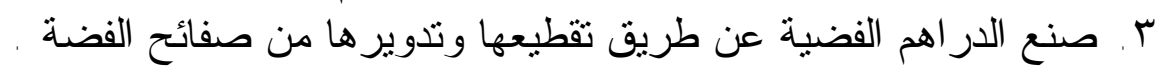

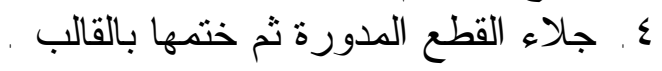
وقد ذكر منصورين بعرة المشرفون عن بالب دار الضرب الأيوبية وكانت في ناحتين

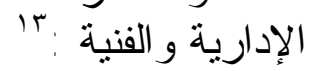

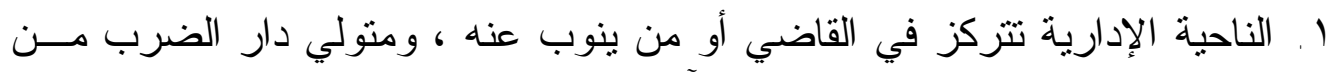

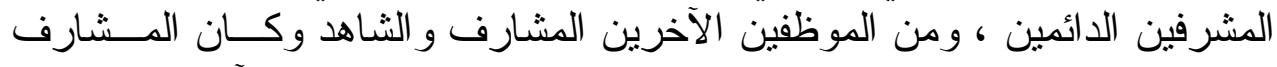

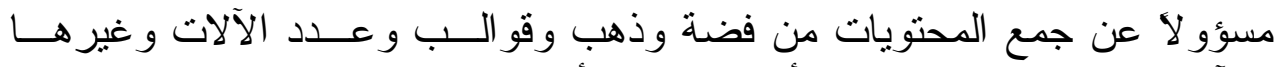

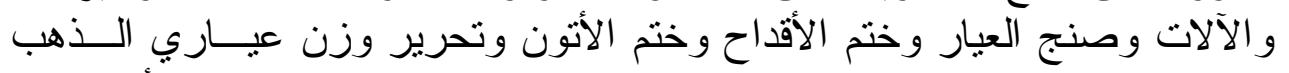

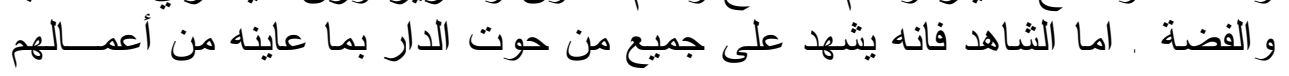

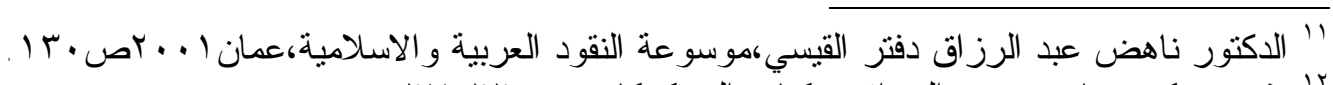

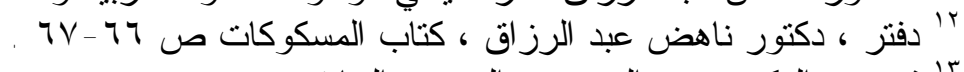

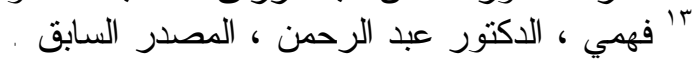


و مباشرته إياهم ومقابلته على الحساب وخطه وبذلك عليه . أما الناحية الفنية وهي

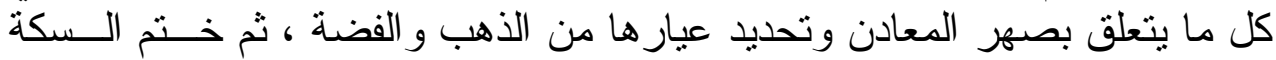

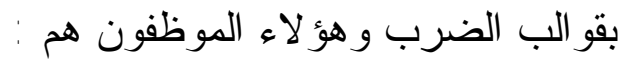

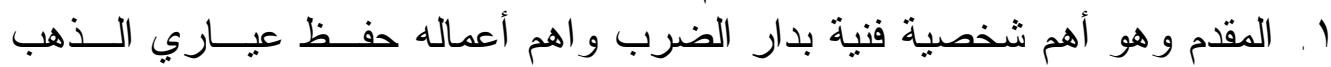

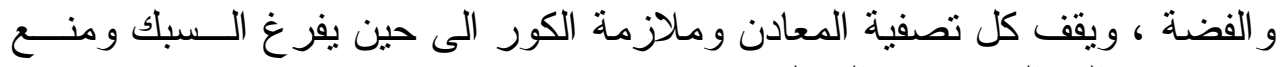

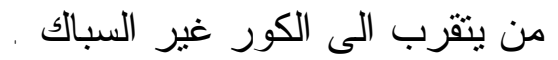
r. . النقاش و عملة نقش السكة أي نقش القو الب المطلوبة ويكون النقش مقلوبة و عميقــة

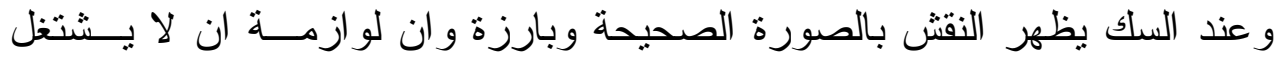

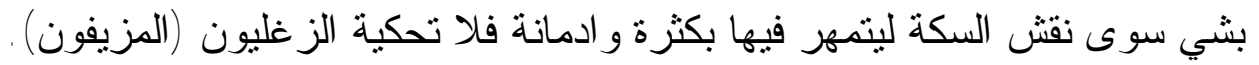

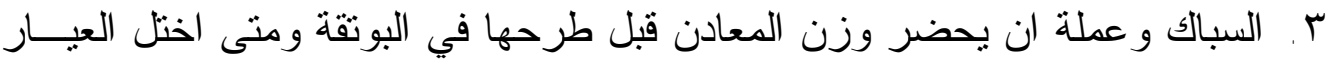

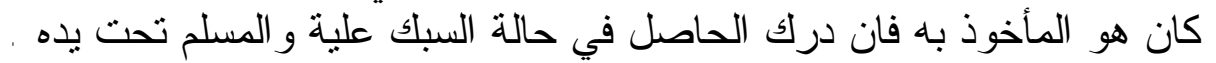

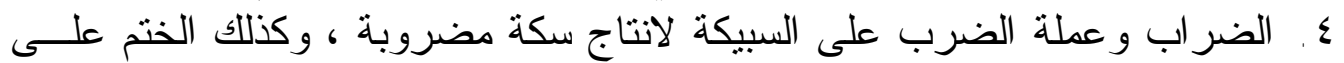

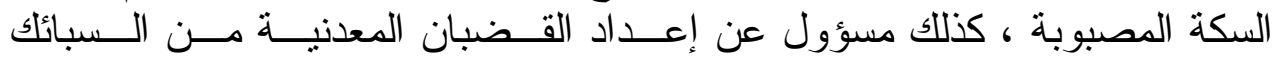

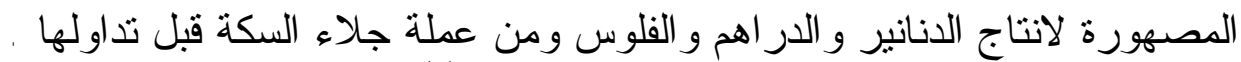

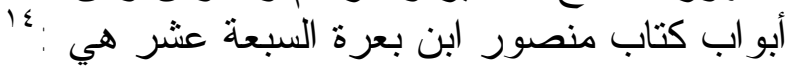

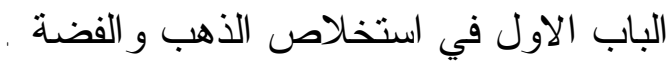

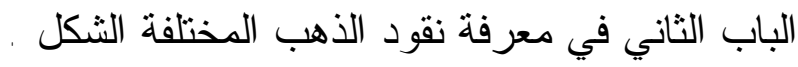

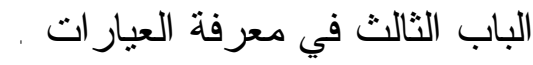

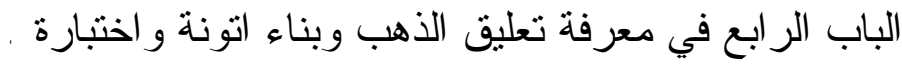

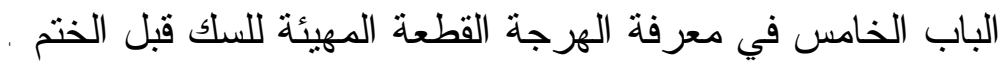

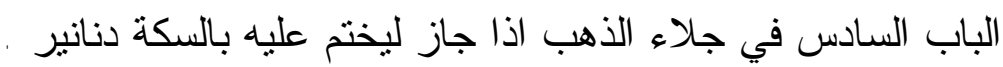

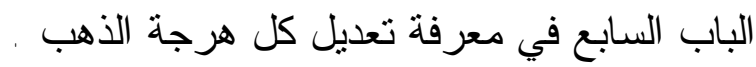

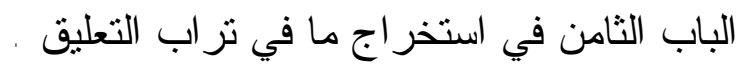
الباب التاسع في تصفية الفضة و النقرة .

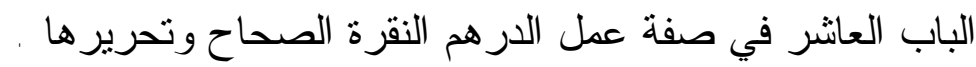

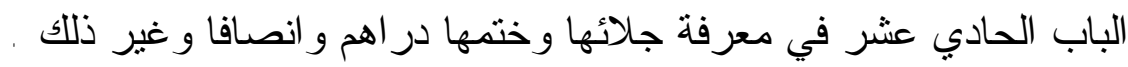

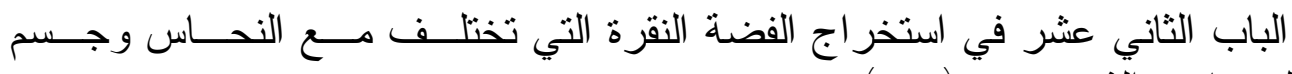

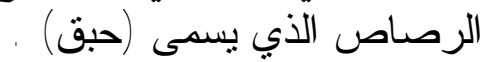

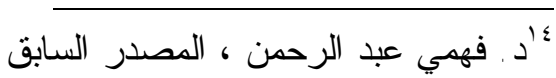




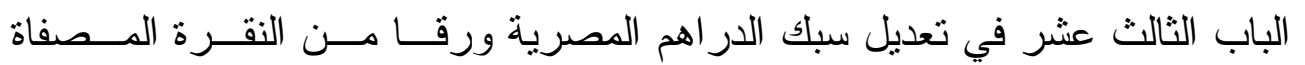

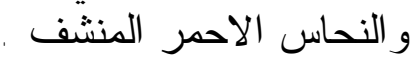

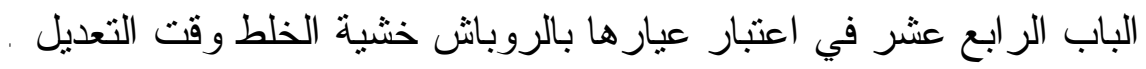

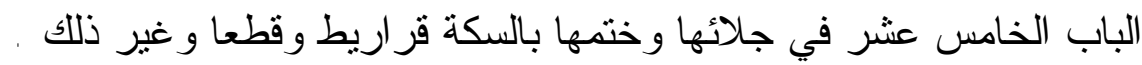

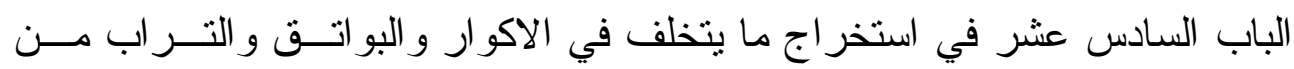

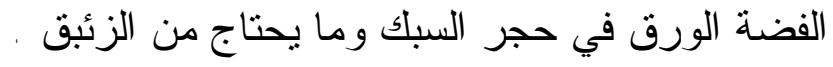

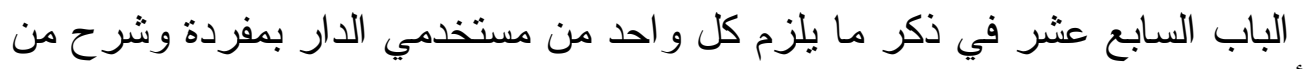

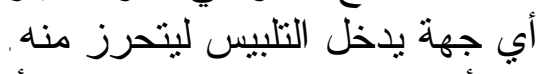

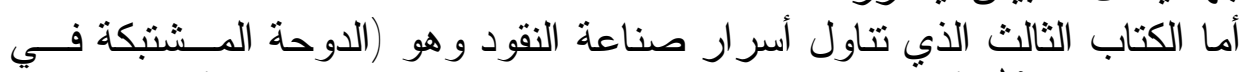

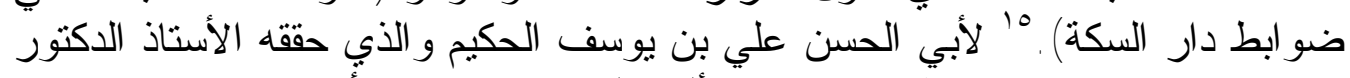

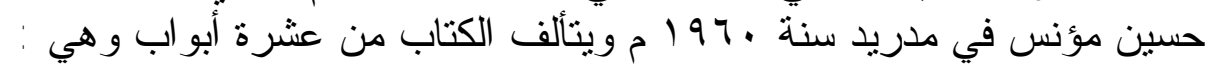

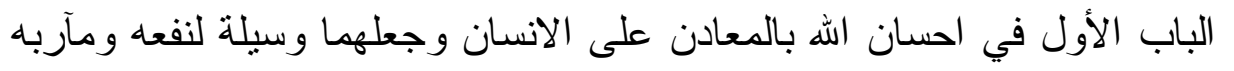

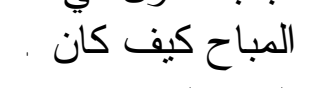

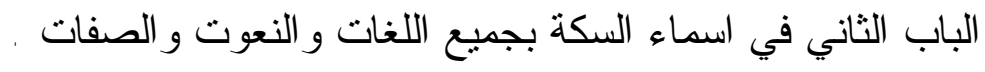

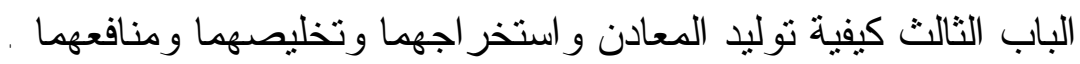

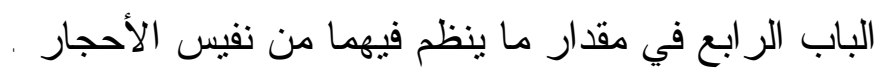

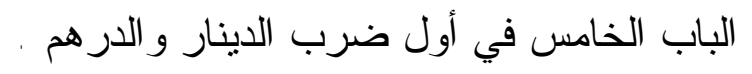

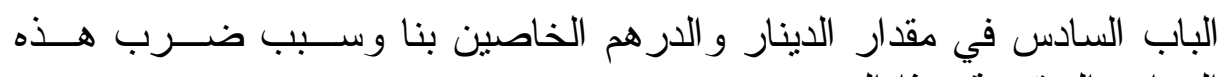

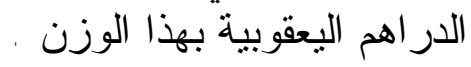

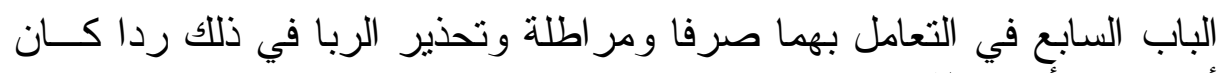

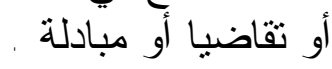

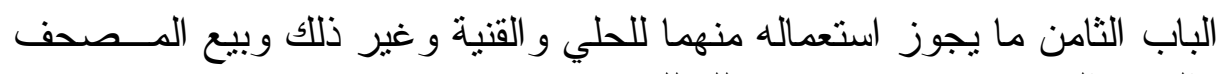

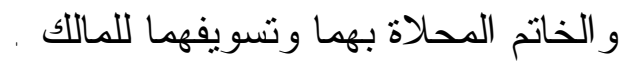

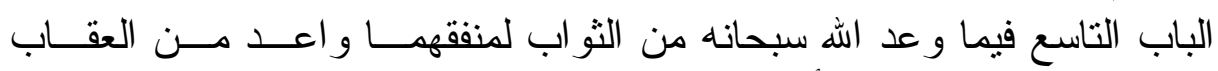

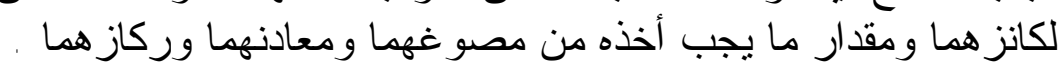

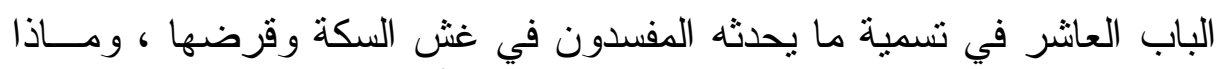

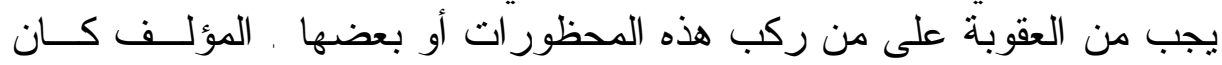

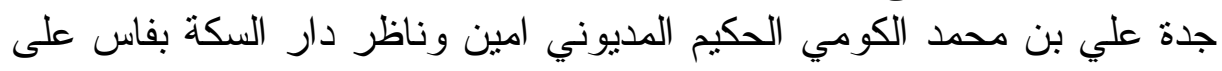

ما الحكيم ، علي بن يوسف : الدوحة المشتبكة في ضو ابط دار السكة ، نشرها الدكتور حسين مؤنس

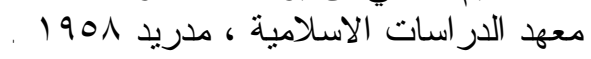


دراسات في آثار الوطن العربي 11

عهد السلطان ابي يوسف بن عبد الحق المريني وذلك سنة ؟ ؟ هجرية و انسـهـ

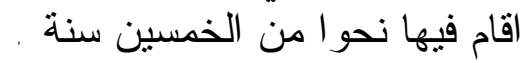

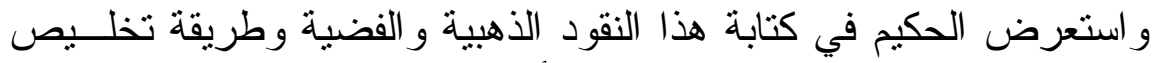

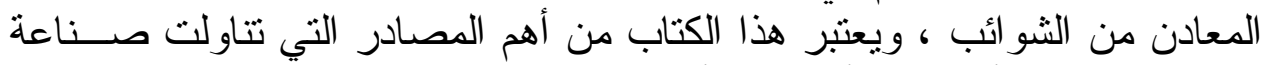

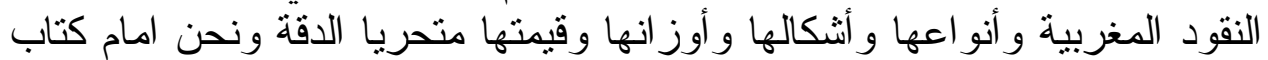

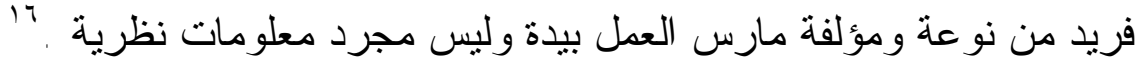

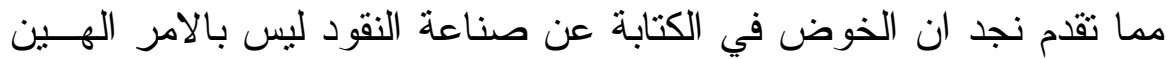

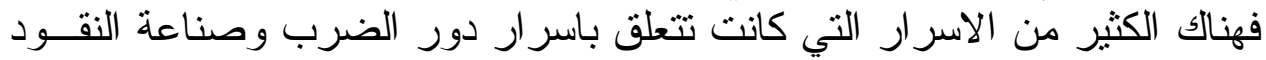

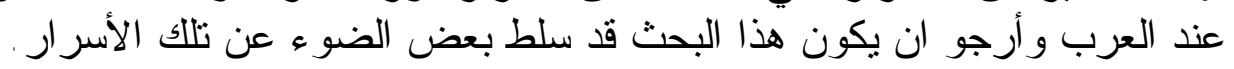


دراسات في آثار الوطن العربي 11

مر اجع البحث

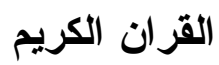

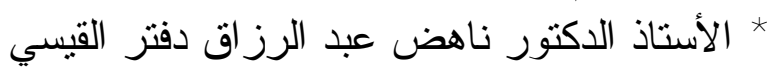

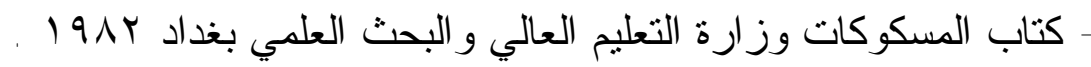

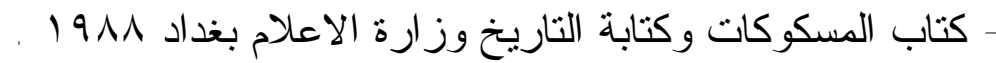

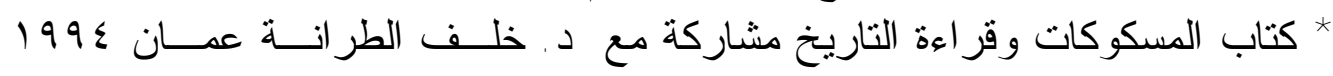

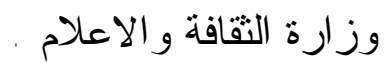

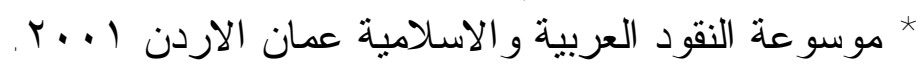

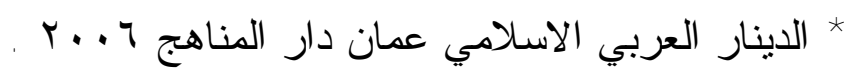

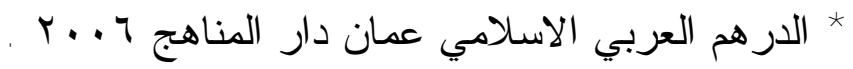

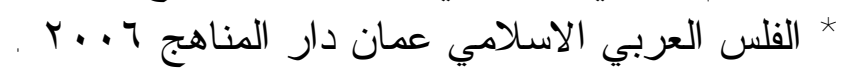

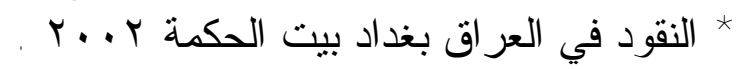

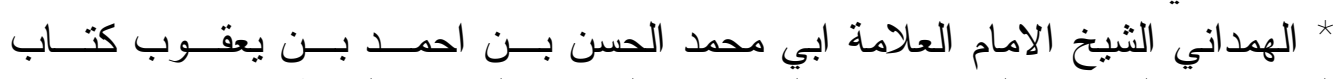

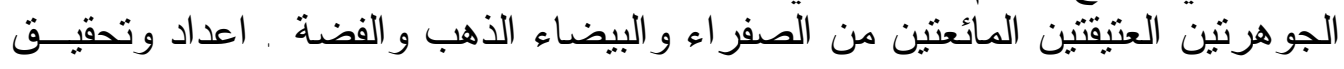

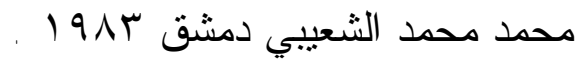

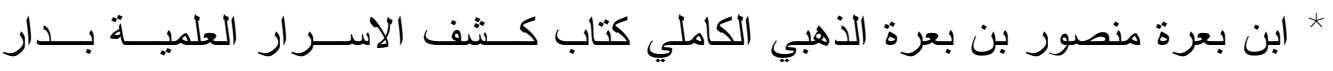

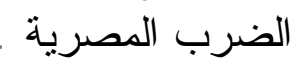
* تحقيق الاستاذ دكتور عبد الرحمن فهمي القاهرة 1977 الحكيم ابو الحسن علي بـن يوسف . منيف الان. الدوحة المشتبكة في ظو ابط دار السكة حققة وذيله بجامع مفردات حسين مــؤنس

مدريد . 197 